\title{
The use of soil biostructures created by soil fauna ecosystem engineers fed with different organic materials as inoculum source of arbuscular mycorrhiza fungi on cocoa seedling
}

\author{
Laode Muhammad Harjoni Kilowasid*, Muhammad Fahyu Sanjaya, Laode Sabaruddin, Rachmawati Hasid, \\ Darwis Sulaeman, Andi Nurmas
}

Department of Agrotechnology, Faculty of Agriculture, Halu Oleo University, Indonesia

\begin{tabular}{|c|c|}
\hline ARTICLE INFO & ABSTRACT \\
\hline $\begin{array}{l}\text { Article history } \\
\text { Submitted: 2021-05-26 } \\
\text { Accepted: 2021-12-03 } \\
\text { Available online: 2021-12-29 } \\
\text { Published regularly: December } \\
2021\end{array}$ & $\begin{array}{l}\text { Soil fauna as ecosystem engineers has the ability to create soil biostructures, with the } \\
\text { capacity to save arbuscular mycorrhizal fungi (AMF) spores. This study, therefore, aimed at } \\
\text { investigating the AMF spore density in the biostructures created by cooperation between } \\
\text { earthworms and ants with a different organic matter composition, and to analyze the } \\
\text { biostructures' potential as a source of AMF inoculum on cocoa seedlings. In the first } \\
\text { experiment, a combination of earthworms }(0,10 \text {, or } 20 \text { pieces) and ants }(0,10 \text {, or } 20 \text { pieces) } \\
\text { composition, as well as a mixture of Gliricidia sepium leaves (GSL), cocoa shell bean (CSB), } \\
\text { and sago dregs (SD)(w/w/w) was tested. Meanwhile, in the second experiment, the effect } \\
\text { of biostructures on cocoa seedlings grown in unsterile soil was examined. According to the } \\
\text { results, the highest ( } 46.67 \pm 13.65) \text { AMF spore density was obtained using } 20 \\
\text { earthworms }+10 \text { ants with } 50 \% G S L+50 \% C S B+0 \% S D \text { treatment, the lowest ( } 12.67 \pm 3.78) \\
\text { spore count was obtained using } 20 \text { earthworms }+10 \text { ants with } 25 \% G S L+25 \% C S B+50 \% S D \\
\left.\text { The total AMF spores were positively correlated ( } r^{2}=0.74\right) \text { with the total P, but negatively } \\
\left.\text { correlated ( } r^{2}=-0.53\right) \text { with the C/N ratio. Therefore, biostructure application increased } \\
\text { AMF spores number in the rhizosphere and the percent infection. Furthermore, } \\
\text { biostructures resulting from the collaborative activity between different soil fauna } \\
\text { ecosystem engineers were able to facilitate the germination of AMF spores and infect plant } \\
\text { roots growing in non-sterile soil. }\end{array}$ \\
\hline
\end{tabular}

How to Cite: Kilowasid, L.M.H., Sanjaya, M.F., Sabaruddin, L., Hasid, R., Sulaeman,D., Nurmas, A. (2021). The use of soil biostructures created by soil fauna ecosystem engineers fed with different organic materials as inoculum source of arbuscular mycorrhiza fungi on cocoa seedling. Sains Tanah Journal of Soil Science and Agroclimatology, 18(2): 166-176. https://dx.doi.org/10.20961/stjssa.v18i2.51500

\section{INTRODUCTION}

Soil fauna as an ecosystem engineer has the capacity to create a new aggregate of soil containing numerous microbes useful for agriculture, forestry, and the environment (Jouquet et al., 2012). A study by Taylor et al. (2019) categorized earthworms and ants as soil ecosystem engineers. New aggregates, also known as biostructures, are created from these organisms' activities while mixing organic matter with soil mineral particles (Zanella, Ponge, Topoliantz, et al., 2018). The form of the biostructure created depends largely on the type of soil fauna concerned (Forey et al., 2018). Biostructures formed from the activity of earthworms are known as cast, while counterparts generated by the activity of ants are known as nests or soil mounds (Bottinelli et al., 2015; Cunha et al., 2016). Both types have the ability to provide energyrich substrates containing signaling molecules, to trigger soil microbial activity and growth of arbuscular mycorrhiza fungi

(Kilowasid et al., 2015; Lavelle et al., 2016; Schultz et al., 2015; Shukla et al., 2016; Wills \& Landis, 2018). The symbioticmutualistic association between AMF and crop roots contributes significantly to expansion in the range of rooting, in order to access soil nutrients and water, and consequently, help plants meet growth needs (Powell \& Bagyaraj, 2017).

The use of AMF as biological technology, in soil quality and fertility improvement, has the potential to minimize commercial $\mathrm{N}$ and $\mathrm{P}$ fertilizer use in the production of food crops, plantation seedlings, and horticulture (Cobb et al., 2018). Indonesia is known as one of the world's cocoa bean producers, where cocoa beans are produced from small farmer plantations. Generally, the farmer's cocoa trees are old, and production continues to decline (Directorate General of Estates, 2019). Thus, there is a need to replace aging plants, with seedlings that have the ability to adapt to poor soil 
fertility and low groundwater availability. According to Bahrun et al. (2018), most small farmers grow cocoa seedlings in polybags filled with unsterilized. Adaptation to poor soil fertility and water deficit conditions of cocoa seedlings can be further improved by the application of AMF spore inoculum (Moreira et al., 2018; Seutra Kaba et al., 2021). Azizah Chulan (1991), reported the inoculation of AMF spores (Scutellospora calospora) produced from a mixture of soil and infected root pieces significantly increased nutrient absorption and growth in cocoa seedlings grown in sterilized soil.

The supply of soluble carbon in the substrate significantly determines AMF spores' ability to germinate and produce infective spores under conditions in the absence of plant roots (Kameoka et al., 2019; Rillig et al., 2020; Sugiura et al., 2020). In addition, AMF's sporulation and ability to colonize the roots are largely determined by the ratio of $N: P$ substrates (Mei et al., 2019). Earthworms and ants are able to jointly create soil biostructures with higher microbial activity, compared to the soil not influenced by the organisms' activity (Franco et al., 2017; Kilowasid et al., 2015) The dissolved carbon, $\mathrm{N}$, total $\mathrm{P}, \mathrm{pH}$, and soil microbial population contents from biostructures produced by the activities of earthworms and ants, are strongly influenced by the type of organic matter consumed by the organisms (Ehrle et al., 2019; Wang et al., 2019; Zanella, Ponge, \& Briones, 2018). Fresh biostructures created by earthworms (Lumbricus terrestris L.) and black ants (Camponatus compressus Fabr.) contain populations of infective mycorrhiza spores (Harinikumar \& Bagyaraj, 1994; Lee et al., 1996). However, further studies on the biostructure potential of ecosystem-engineered soil fauna to develop inoculum mycorrhiza arbuscular infective production system options for effective application at the farmer level in tropical environments, are required. Thus, this study aimed to study the AMF spore density in biostructures created by cooperation between earthworms and ants on soil enhanced with a composition of different organic matter types, as well as to analyze the biostructures potential, as an inoculum source of AMF spore on cocoa seedlings.

\section{MATERIAL AND METHODS}

Table 1. The treatment combinations of soil fauna proportions and mixtures of three different organic matter types.

\begin{tabular}{cc}
\hline Symbol of treatments & Description \\
\hline F0B0 & without soil fauna and organic matter \\
F1B0 & 10 earthworms +20 ants and without organic matter \\
F1B1 & 10 earthworms +20 ants with $25 \% \mathrm{GSL}+50 \% \mathrm{CSB}+25 \% \mathrm{SD}$ \\
F1B2 & 10 earthworms +20 ants with $50 \% \mathrm{GSL}+25 \% \mathrm{CSB}+25 \% \mathrm{SD}$ \\
F1B3 & 10 earthworms +20 ants with $25 \% \mathrm{GSL}+25 \% \mathrm{CSB}+50 \% \mathrm{SD}$ \\
F1B4 & 10 earthworms+20 ants with $50 \% \mathrm{GSL}+50 \% \mathrm{CSB}+0 \% \mathrm{SD}$ \\
F1B5 & 10 earthworms+20 ants with $50 \% \mathrm{GSL}+0 \% \mathrm{CSB}+50 \% \mathrm{SD}$ \\
F1B6 & 10 earthworms+20 ants with $0 \% \mathrm{GSL}+50 \% \mathrm{CSB}+50 \% \mathrm{SD}$ \\
F2B0 & 20 earthworms+10 ants and without organic matter \\
F2B1 & 20 earthworms+10 ants with $25 \% \mathrm{GSL}+50 \% \mathrm{CSB}+25 \% \mathrm{SD}$ \\
F2B2 & 20 earthworms+10 ants with $50 \% \mathrm{GSL}+25 \% \mathrm{CSB}+25 \% \mathrm{SD}$ \\
F2B3 & 20 earthworms +10 ants with $25 \% \mathrm{GSL}+25 \% \mathrm{CSB}+50 \% \mathrm{SD}$ \\
F2B4 & 20 earthworms +10 ants with $50 \% \mathrm{GSL}+50 \% \mathrm{CSB}+0 \% \mathrm{SD}$ \\
F2B5 & 20 earthworms+10 ants with $50 \% \mathrm{GSL}+0 \% \mathrm{CSB}+50 \% \mathrm{SD}$ \\
F2B6 & 20 earthworms+10 ants and $0 \% \mathrm{GSL}+50 \% \mathrm{CSB}+50 \% \mathrm{SD}$ \\
\hline
\end{tabular}

Remarks: GSL = G. sepium leaves; $\mathrm{CSB}=$ cocoa bean shell; $\mathrm{SD}=$ sago dreg. 
All the collected materials (sago dregs, cocoa bean shells, and leaves of $G$. sepium) were oven-dried, pulverized using a kitchen blender, and sieved in a wire mess with a $<2 \mathrm{~mm}$ pore opening (Sanjaya et al., 2020). One sample of each OM was analyzed for chemical attributes include organic carbon using Walkley-Black method, total-N using the Kjeldahl method, $\mathrm{C} / \mathrm{N}$ ratio, total- $\mathrm{P}$, and total- $\mathrm{K}$ prepared using the wetdigestion method (Vogt et al., 2015). Table 2 shows the chemical attributes of each collected organic material.

Furthermore, soil (0-10 cm depth) was obtained from a smallholder farmer cocoa plantation aged over 15 years old in the Konda District, South Konawe regency. Subsequently, the soil samples were wind-dried and sieved using a $<4 \mathrm{~mm}$ sieve pore opening. A total of $100 \mathrm{~g}$ of each OM composition (treatment) was then mixed with $1.5 \mathrm{~kg}$ of soil in a blockshaped reactor comprised of a multiplex board, measuring 25 $\mathrm{cm} \times 21 \mathrm{~cm} \times 21 \mathrm{~cm}$ (Figure 1). The substrate in each reactor was then watered with tap water until saturated and left until no water drips through the five small holes on the reactor's bottom surface (Sanjaya et al., 2020). It took about 24 hours to get the substrate moisture condition that allow the mobility of ants on the substrate surface in the reactor.

Earthworms measuring 5-6 cm in length were released on tissues paper surface moistened with tap water and left until no more casts were released from the anus. After emptying stomach contents, earthworms with an individual number according to the treatment (Tabel 1) were released into each soil surface's of the mixture of SD, CBS, and GSL referred onward as organic material. Subsequently, the number of individual ants according to the treatment (Table 1) were released and allowed to enter into the substrate, after the earthworms' bodies were wholly entered into the substrate. Each reactor's entire surface was then covered with a $<2 \mathrm{~mm}$ wire mesh green plastic gauze to prevent earthworms and ants from escaping to leave the reactor and to prevent other organisms from accessing the reactor (Figure 1). This was followed by placing all reactors on plank pads $40 \mathrm{~cm}$ above the ground in a simple structure with a sago leaf roof built under \pm 10 -year-old cacao stands (Figure 2). Moisture content (about 35\% measured with a soil moisture meter, Lutron PMS 714 type) was maintained by spraying $50 \mathrm{ml}$ of tap water on the entire surface of the soil mixture's every two days.

\subsubsection{Estimation of total AMF spore in the biostructures}

After 28 days of incubation, the soil was removed from the reactor, then earthworms and ants were separated from the soil by hand-sorting technique. The soil was air-dried under room conditions, where soil samples were taken to assess the total AMF spores and each reactor's structural chemistry. In addition, a total of $50 \mathrm{~g}$ of biostructure from each reactor was Table 2. Chemical attribute of organic matter. poured into a container containing $500 \mathrm{ml}$ of tap water and stirred to obtain a homogeneous mixture. The suspension was then filtered using 3 series of sieves with sizes of $2 \mathrm{~mm}$, $200 \mu \mathrm{m}$, and $38 \mu \mathrm{m}$, from top to down, respectively. Materials retained on the $200 \mu \mathrm{m}$ and $38 \mu \mathrm{m}$ filters were poured into the tubes containing $20 \% / 60 \%$ concentration of sugar solution. At the end of the spin, the supernatant was poured onto the $38 \mu \mathrm{m}$ sieve and rinsed with water until the sugar solution was drained from the sieves. The retained spores were transferred into plastic Petri dishes (with $85 \mathrm{~mm}$ in diameter) with an arrangement of gridline (size $1 \mathrm{~mm} \times 1$ $\mathrm{mm})$, and counting of AMF spores was done under a dissecting microscope (INVAM, 2019). The total number of AMF spores in each biostructure was then estimated following instructions stated in the INVAM.WVU.EDU. Briefly, the number of AMF spores was counted in 20 randomly selected field views.

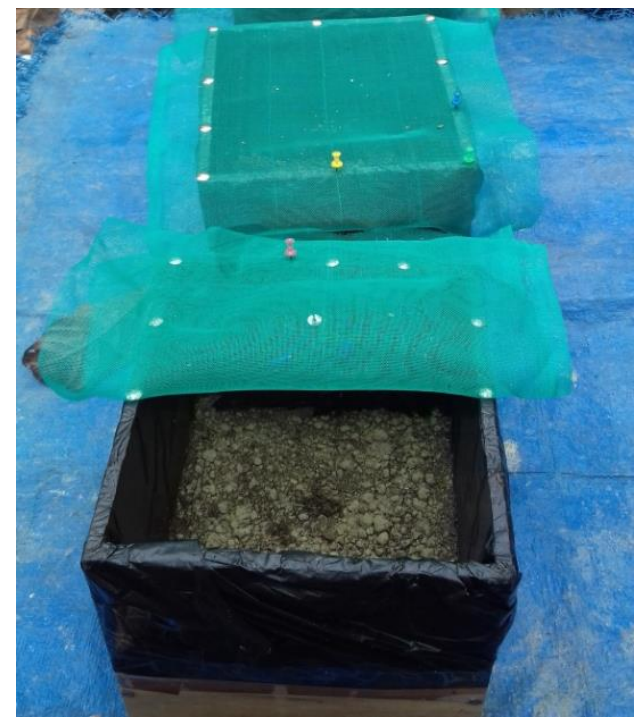

Figure 1: Reactor used for the experiment

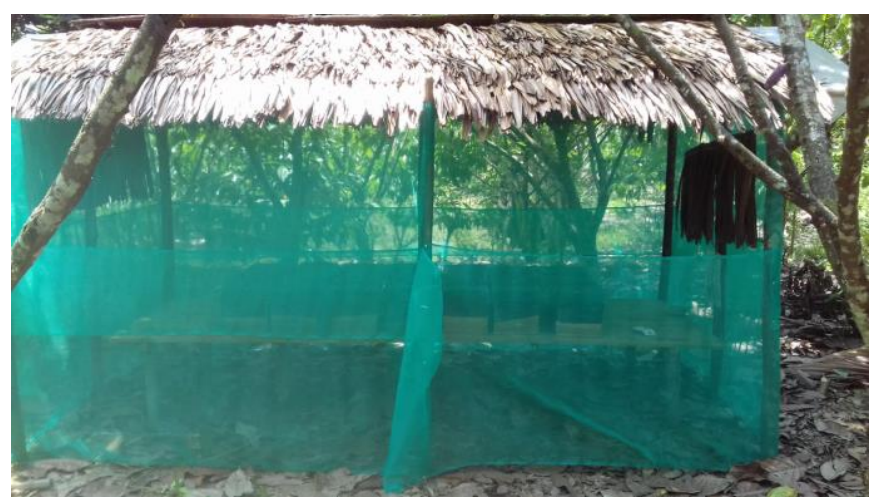

Figure 2. Reactors placed inside sago hut under \pm 10 -yearold cacao stands

\begin{tabular}{lccccc}
\hline & \multicolumn{5}{c}{ Parameters } \\
\cline { 2 - 6 } Organic matter type & $\begin{array}{c}\text { Organic Carbon } \\
\text { (\%) }\end{array}$ & $\begin{array}{c}\text { Total-Nitrogen } \\
(\%)\end{array}$ & $\begin{array}{c}\text { C/N } \\
\text { ratio }\end{array}$ & $\begin{array}{c}\text { Total-Phosphorus } \\
\text { (\%) }\end{array}$ & $\begin{array}{c}\text { Total- } \\
\text { Potassium(\%) }\end{array}$ \\
\hline Cocoa shell bean & 2.62 & 0.58 & 4.52 & 5.32 & 106.42 \\
G. sepium leaf powder & 2.52 & 1.03 & 2.45 & 5.09 & 114.16 \\
Sago dregs & 2.73 & 0.53 & 5.16 & 3.57 & 8.08 \\
\hline
\end{tabular}


Table 3. Soil physicochemical character of soil growing medium where cocoa seedlings were planted.

\begin{tabular}{|c|c|c|c|}
\hline Parameter & Method & Unit & Value \\
\hline \multicolumn{4}{|l|}{ Soil fraction: } \\
\hline Sand & Pippete & $\%$ & 38.19 \\
\hline Silt & Pippete & $\%$ & 36.69 \\
\hline Clay & Pippete & $\%$ & 25.21 \\
\hline $\mathrm{pH}_{\mathrm{H} 2 \mathrm{O}(1: 5)}$ & & - & 6.81 \\
\hline $\mathrm{pH}_{\mathrm{KCl}(1: 5)}$ & & - & 6.14 \\
\hline C-org & Walkey \& Black & $\%$ & 2.77 \\
\hline Total-Nitrogen & Kjeldahl & $\%$ & 0.49 \\
\hline Total-Phosphorus & $\mathrm{HCl} 25 \%$ & Ppm & 871.32 \\
\hline Available-Phosphorus & Olsen & Ppm & 130.40 \\
\hline $\mathrm{Ca}$ & $\mathrm{NH} 40 \mathrm{Ac}(\mathrm{pH} 7.0)$ & $\mathrm{cmol}^{(+)} / \mathrm{kg}$ & 8.27 \\
\hline $\mathrm{Mg}$ & NH4Oac (pH 7.0) & $\mathrm{cmol}^{(+)} / \mathrm{kg}$ & 2.77 \\
\hline K & NH4Oac (pH 7.0) & $\mathrm{cmol}^{(+)} / \mathrm{kg}$ & 2.46 \\
\hline $\mathrm{Na}$ & NH4Oac (pH 7.0) & $\mathrm{cmol}^{(+)} / \mathrm{kg}$ & 0.21 \\
\hline CEC & NH4Oac (pH 7.0) & $\mathrm{cmol}^{(+)} / \mathrm{kg}$ & 16.52 \\
\hline Base saturation & & $\%$ & 82.98 \\
\hline $\mathrm{Al}$ & $\mathrm{KCl} 1 \mathrm{~N}$ & $\mathrm{cmol}^{(+)} / \mathrm{kg}$ & not detected \\
\hline $\mathrm{H}$ & $\mathrm{KCl} 1 \mathrm{~N}$ & $\mathrm{cmol}^{(+)} / \mathrm{kg}$ & 0.13 \\
\hline $\mathrm{Fe}$ & DTPA & Ppm & 65.18 \\
\hline $\mathrm{Cu}$ & DTPA & Ppm & 3.60 \\
\hline $\mathrm{Zn}$ & DTPA & Ppm & 32.48 \\
\hline $\mathrm{Mn}$ & DTPA & Ppm & 69.99 \\
\hline
\end{tabular}

The total field views were determined based on the ratio of the area of the plastic petri dish to the view field area of the ocular dissecting microscope at a magnification, where the AMF spores can be distinguished from other objects. The total AMF spores in suspension were estimated utilizing the average of AMF spores per field view multiplied with the total field views in plastic Petri dishes used. Furthermore, the total AMF spores were expressed as total AMF spore per biostructure weight where the spores were extracted.

\subsubsection{Chemical characterization of the soil biostructures}

The remaining biostructures' in the reactors were winddried for 48 hours inside a well-ventilated room, then sieved using a $<4 \mathrm{~mm}$ sieve pore opening, then subjected to chemical analysis, including $\mathrm{pH}$ using a $\mathrm{pH}$ meter with a $1: 5(\mathrm{w} / \mathrm{v})$ soilwater ratio, C-org using the Walkley-Black method,total- $\mathrm{N}$ using the Kjeldahl method, $\mathrm{C} / \mathrm{N}$ ratio, total- $\mathrm{P}$ and total- $\mathrm{K}$ using a $25 \% \mathrm{HCl}$ extractor (Vogt et al., 2015).

\subsection{Second Experiment}

\subsubsection{The site and experimental design}

The second experiment was conducted in Tanea Village, Konda District, Konawe Selatan Regency, Southeast Sulawesi, from February to May 2019. In this experiment, physiologically ripe criollo cocoa pods were obtained from local farmers' cocoa nurseries in Konawe Selatan Regency, Southeast Sulawesi. Cocoa beans were removed from the pods, and pithy, healthy, large beans (about $2.5 \mathrm{~cm}$ in length) were selected. The seeds were mixed with ashed rice husk, kneaded until the pulp of the seed's surface coating was exposed, cleaned under running water, then the cleaned seeds were laid on the carbonized rice husk to germinate, and left to grow until roots emerged.
Table 3 shows the physicochemical characteristics of the soil used as a growing medium in this study. For this experiment, a total of $500 \mathrm{~g}$ of soil from the cocoa plantation was mixed with goat manure in a 2:1 ratio $(\mathrm{v} / \mathrm{v})$, placed in a polybag, and soaked in a container filled with water, until the entire surface had been inundated. The bags were removed from the container after air bubbles had stopped emerging from the soil and then left overnight. A total of $100 \mathrm{~g}$ of each biostructure produced from the first experiment was spread on the soil surface on each polybag. The germinated three-day-old cocoa seedlings were transplanted into polybags filled with soil+goat manure and biostructure, produced from the reactor. The experiment was established in the nursery following RCBD with three replicates. The nursery is made of wood, with a roof made of woven sago leaves, and $<2 \mathrm{~mm}$ mesh nylon net walls. The seedlings were maintained for 12 weeks.

\subsubsection{Growth measurement of cocoa seedling}

At 2, 4, 6, 8, 10, and 12 weeks after planting (WAP), the plants' height was measured, and the leaves were counted. At the end of the experiment, the seedlings were separated into shoot and root parts. The shoots were oven-dried at $60^{\circ} \mathrm{C}$ for 48 hours, and the dry weight was measured.

\subsubsection{Estimation of total AMF spore from rhizosphere and root infection}

Soil samples were obtained from the rhizosphere area for total AMF spore counting, using the procedure mentioned above. Meanwhile, the roots were washed with tap water, soaked in $10 \% \mathrm{KOH}$, and oven-dried at $90^{\circ} \mathrm{C}$ for 20 minutes. The roots were then rinsed with water, immersed in $\mathrm{H}_{2} \mathrm{O}_{2}$ for 12 hours, and the procedure was repeated once again. Roots washed from the $\mathrm{H}_{2} \mathrm{O}_{2}$ were stained in $0.05 \%$ aniline blue solution, and AMF infection on stained root pieces were observed under a microscope (Dhar \& Mridha, 2012). 


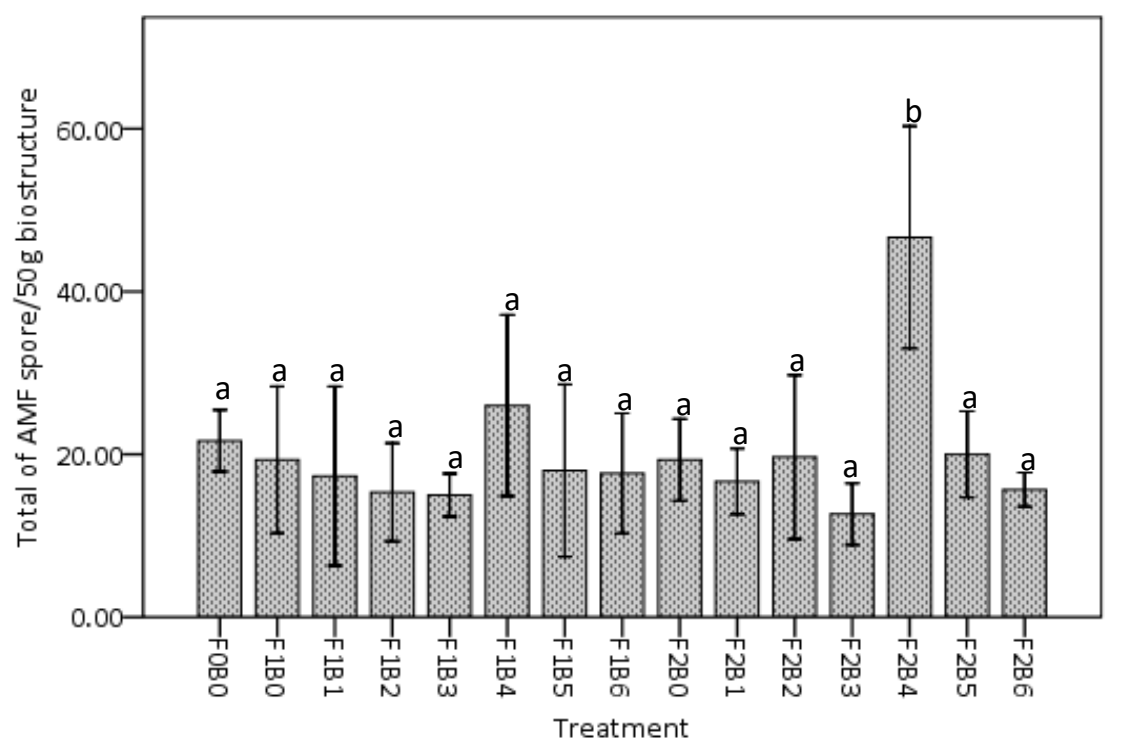

Figure 3. Number of AMF spores in biostructure produced from different treatments.

Table 4. Bivariate Spearman's $r^{2}$ correlation $(p<0.05)$ between the AMF spore number and the biostructure's chemical attribute.

\begin{tabular}{|c|c|c|c|c|c|c|c|}
\hline & $\mathrm{pH}$ & Organic C & Tot-N & $\mathrm{C} / \mathrm{N}$ & Tot-P & Tot-K & AMF spore \\
\hline $\mathrm{pH}$ & & -0.41 & -0.41 & 0.19 & 0.00 & -0.11 & -0.12 \\
\hline Organic C & & & 0.46 & 0.00 & 0.33 & 0.16 & 0.24 \\
\hline Tot-Nitrogen & & & & -0.84 & 0.29 & 0.46 & 0.40 \\
\hline $\mathrm{C} / \mathrm{N}$ & & & & & -0.28 & -0.49 & -0.53 \\
\hline Tot-P & & & & & & 0.35 & 0.74 \\
\hline Tot-K & & & & & & & 0.25 \\
\hline
\end{tabular}

\subsection{Statistical Analysis}

The data were subject to analysis of variance, and the means of treatments were compared using Duncan's Multiple Range Test (DMRT) also correlation test, at a significance level of $p<0.05$.

\section{RESULTS}

The results showed a significant difference in the number of AMF spores within biostructures created by collaborative activity between earthworms and ants fed with a mixture of three types of OM (Figure 3). Soil from the cocoa plantation treated with F2B4 $(20$ earthworms +10 ants with $50 \% \mathrm{GSL}+50 \% \mathrm{CBS}$ and no SD) treatment produced a biostructure containing the highest total AMF spores (47 spores / $50 \mathrm{~g}$ of biostructure) (Figure 3). The total AMF spores in biostructures produced from the F2B4 treatment differed significantly from other treatments (Figure 3 ). The lowest spore count was obtained in F2B3 (20 earthworms+10 ants with $25 \% \mathrm{GSL}+25 \% \mathrm{CSB}+50 \% \mathrm{SD}$ ) (Figure 3).

Spearman's rs bivariate correlation showed the number of AMF spores had a significant positive correlation with total $P$ $\left(r^{2}=0.74\right.$ at $\left.p<0.05\right)$, but was insignificant with $\mathrm{pH}\left(r^{2}=-0.12\right)$, total $\mathrm{N}\left(\mathrm{r}^{2}=0.40\right), \mathrm{C}$-org $\left(\mathrm{r}^{2}=0.24\right)$, total $\mathrm{K}\left(\mathrm{r}^{2}=0.25\right)$, and with negative $\left(r^{2}=-0.53\right)$ correlation with $C / N$ ratio at $p>0.05$ level (Table 4).

The height of cocoa seedlings treated with soil without soil fauna and organic matter (control) was higher, as compared to counterparts treated with soil from biostructure (Table 5). At 2 and 4 weeks after application, the height of cocoa seedlings inoculated with FOBO was the tallest $(9.88 \pm 2.14 \mathrm{~cm}$ and $20.54 \pm 2.69 \mathrm{~cm}$, respectively) and this differed significantly (Table 5) with F1B5 (10 earthworms+20 ants with $50 \%$ GSL+ 0\% $\mathrm{CSB}+50 \% \mathrm{SD}$ ) and F1B0 (10 earthworms +20 ants and without organic matter) treatments, but comparable with the other treatments (Table 5). At 6 weeks after biostructure application, there was a significant difference (Table 5) in height, between FOBO (control) seedlings, applied with biostructures in treatments F1B5 (10 earthworms+20ants with 50\% $\mathrm{GSL}+0 \% \mathrm{CSB}+50 \% \mathrm{SD}$ ) and F2B1 (20 earthworms+10 ants with $25 \% \mathrm{GSL}+50 \% \mathrm{CSB}+25 \% \mathrm{SD}$ ) (Table 4). At 8 weeks after application, a significant difference in seedling height was observed between the control, as compared to F1B5 (10 earthworms+20ants with $50 \% \mathrm{GSL}+0 \% \mathrm{CSB}+50 \% \mathrm{SD}$ ) and $\mathrm{F} 2 \mathrm{~B} 1$ (20 earthworms +10 ants with $25 \% \mathrm{GSL}+50 \% \mathrm{CSB}+25 \% \mathrm{SD}$ ) treatments. This observation on F1B5 and F2B1 treated seedlings was carried over at weeks 10 and 12 .

The number of leaves of cocoa seedlings at 2, 6, 8, 10, and 12 weeks after biostructure application followed the same trend as in plant height (Table 6). Cocoa seedlings treated in FOBO biostructure, gave consistently the highest number of leaves throughout the 12 week observation period except at week 4 where there was no significant effect of the treatment on the number of leaves of cocoa seedling grown in the 15 treatment combinations (Table 6). 
Table 5. Cocoa seedling height $(\mathrm{cm})$ during the twelve weeks growth period, after biostructure application.

\begin{tabular}{|c|c|c|c|c|c|c|}
\hline \multirow{2}{*}{$\begin{array}{c}\text { Biostructure } \\
\text { sources }\end{array}$} & \multicolumn{6}{|c|}{ week after biostructure application } \\
\hline & 2 & 4 & 6 & 8 & 10 & 12 \\
\hline FOBO & $9.88 \pm 2.14 c$ & $20.54 \pm 2.69 b$ & $21.74 \pm 2.14 c$ & $21.94 \pm 1.76 c$ & $22.88 \pm 2.03 c$ & $25.17 \pm 2.33 c$ \\
\hline F1B0 & $8.44 \pm 0.58 b c$ & $19.08 \pm 0.70 b$ & $19.47 \pm 1.00 \mathrm{bc}$ & $20.11 \pm 1.07 b c$ & $21.10 \pm 1.24 b c$ & $22.22 \pm 1.70 b c$ \\
\hline F1B1 & $7.92 \pm 2.92 b c$ & $18.61 \pm 3.06 b$ & $18.88 \pm 3.00 \mathrm{bc}$ & $19.00 \pm 3.00 \mathrm{bc}$ & $20.18 \pm 3.04 b c$ & $22.17 \pm 4.02 b c$ \\
\hline F1B2 & $7.04 \pm 1.03 a b c$ & $18.90 \pm 1.15 b$ & $19.00 \pm 1.09 \mathrm{bc}$ & $20.00 \pm 1.52 b c$ & $20.55 \pm 0.58 b c$ & $21.98 \pm 1.00 \mathrm{bc}$ \\
\hline F1B3 & $6.84 \pm 0.63 a b c$ & $18.08 \pm 0.57 b$ & $18.50 \pm 0.50 \mathrm{bc}$ & $19.22 \pm 0.50 \mathrm{bc}$ & $20.33 \pm 0.60 b c$ & $21.36 \pm 1.04 b c$ \\
\hline F1B4 & $6.28 \pm 1.93 a b c$ & $17.50 \pm 2.28 \mathrm{ab}$ & $17.83 \pm 1.04 \mathrm{bc}$ & $18.88 \pm 1.38 \mathrm{bc}$ & $19.78 \pm 1.41 b c$ & $21.93 \pm 2.69 b c$ \\
\hline F1B5 & $4.08 \pm 1.17 a$ & $13.13 \pm 6.06 a$ & $13.22 \pm 6.03 a$ & $13.55 \pm 6.43 a$ & $14.33 \pm 6.80 \mathrm{a}$ & $15.03 \pm 7.41 a$ \\
\hline F1B6 & $7.92 \pm 2.17 b c$ & $17.80 \pm 0.40 \mathrm{ab}$ & $18.44 \pm 0.91 b c$ & $19.05 \pm 0.58 b c$ & $19.25 \pm 0.50 \mathrm{bc}$ & $20.77 \pm 0.62 b c$ \\
\hline $\mathrm{F} 2 \mathrm{BO}$ & $7.83 \pm 0.79 b c$ & $17.55 \pm 1.45 a b$ & $17.66 \pm 1.52 \mathrm{bc}$ & $18.22 \pm 1.50 \mathrm{bc}$ & $18.75 \pm 1.50 \mathrm{bc}$ & $19.36 \pm 1.84 a b c$ \\
\hline F2B1 & $5.94 \pm 1.77 a b c$ & $15.22 \pm 3.50 \mathrm{ab}$ & $16.17 \pm 4.04 a b$ & $16.55 \pm 4.28 \mathrm{ab}$ & $16.90 \pm 4.25 \mathrm{ab}$ & $17.97 \pm 4.55 \mathrm{ab}$ \\
\hline F2B2 & $7.12 \pm 2.06 a b c$ & $17.16 \pm 3.23 a b$ & $18.00 \pm 2.64 \mathrm{bc}$ & $19.11 \pm 1.01 b c$ & $20.31 \pm 1.08 b c$ & $21.56 \pm 2.03 b c$ \\
\hline F2B3 & $6.22 \pm 3.53 a b c$ & $16.23 \pm 3.20 \mathrm{ab}$ & $17.76 \pm 1.18 \mathrm{bc}$ & $18.22 \pm 0.96 b c$ & $19.21 \pm 0.76 b c$ & $20.24 \pm 0.88 b c$ \\
\hline F2B4 & $5.66 \pm 2.39 a b$ & $17.51 \pm 1.45 a b$ & $18.16 \pm 1.69 b c$ & $18.22 \pm 1.07 \mathrm{bc}$ & $18.84 \pm 1.49 \mathrm{bc}$ & $19.96 \pm 1.44 b c$ \\
\hline F2B5 & $6.70 \pm 0.30 a b c$ & $17.33 \pm 0.51 \mathrm{ab}$ & $17.83 \pm 0.92 b c$ & $18.22 \pm 0.50 \mathrm{bc}$ & $19.05 \pm 0.25 b c$ & $20.60 \pm 0.82 b c$ \\
\hline F2B6 & $7.30 \pm 0.87 a b c$ & $16.75 \pm 1.43 a b$ & $17.20 \pm 0.80 \mathrm{bc}$ & $17.33 \pm 0.88 \mathrm{bc}$ & $18.58 \pm 1.60 \mathrm{bc}$ & $20.23 \pm 2.28 b c$ \\
\hline
\end{tabular}

Remarks: Numbers (mean \pm sd. $n=3$ ) followed by different letters in the same column indicate significant differences, according to Duncan's Multiple Range Test (DMRT) at the $p<0.05$ level.

Table 7 shows the shoot dry weight, AMF spores count in rhizospheric soil and percentage of infected roots at 12 weeks after biostructure application. The highest $(38 \pm 7.40$ AMF spores per $50 \mathrm{~g}$ biostructure)number of AMF spores were obtained from the soil treated with F1B6 biostructure (10 earthworms +20 ants with $0 \% \mathrm{GSL}+50 \% \mathrm{CSB}+50 \% \mathrm{SD})$, and this differed significantly from those in the FOBO [(no fauna and OM) (16 \pm 4.70 spores per $50 \mathrm{~g}$ soil)], F1B0 [(10 earthworms +20 ants and without $O M)(19 \pm 4.63$ spores per 50 $\mathrm{g}$ soil)] and F1B4 [(10 earthworms+20 ants with $50 \%$ GSL+50\%CSB+0\% SD)] which had the lowest(15 \pm 7.58 AMF spores per $50 \mathrm{~g}$ soil) (Table 7). AMF infected roots and shoot dry weights obtained from each biostructure treatment were not significant from each other (Table 7).

\section{DISCUSSION}

In this study, the total number of AMF spores was observed to vary between the biostructures created, and this variation is probably related to variations in physicochemical properties (Alimi et al., 2021; Asano et al., 2021). These variations reflect the quality of organic material consumed by the soil fauna (Briones, 2014). The availability of organic C, N, $\mathrm{P}$, and $\mathrm{K}$ is possibly suitable to stimulate spore AMF growth in these biostructures (Salim et al., 2020). The correlation analysis shows the total number of AMF spores was negatively insignificant, compared to the biostructures' $\mathrm{pH}$. The correlation with organic $\mathrm{C}$, total- $\mathrm{N}, \mathrm{C} / \mathrm{N}$ ratio, and total- $\mathrm{K}$ is positively insignificant (Table 4). Several studies also reported an insignificant relationship between total AMF spore density with soil $\mathrm{pH}$, organic $\mathrm{C}$, total- $\mathrm{N}, \mathrm{C} / \mathrm{N}$ ratio (Sivakumar, 2013; Verzeaux et al., 2017). Wang et al. (2015) reported the relationship between AMF spore density and total-P soil was insignificant, whereas in this study a positive significant correlation was found $\left(r^{2}=0.74\right)$ at the $p<0.05$ level (Table 4). There is a positive significant relationship in this study, possibly related to the ecological character of the AMF taxa in the soil biostructure (Melo et al., 2019).

Table 6. Periodic number of cocoa seedling leaves during the 12 weeks growth period after biostructure application.

\begin{tabular}{ccccccc} 
Biostructure & \multicolumn{5}{c}{ Week after biostructure application } \\
\cline { 2 - 7 } sources & 2 & 4 & 6 & 8 & 10 & 12 \\
\hline F0B0 & $\mathbf{2 . 7 7} \pm \mathbf{0 . 6 9 c}$ & $\mathbf{3 . 5 5} \pm \mathbf{0 . 8 3 a}$ & $\mathbf{6 . 0 0} \pm \mathbf{0 b}$ & $\mathbf{7 . 6 6} \pm \mathbf{0 . 8 8 b}$ & $\mathbf{7 . 7 7} \pm \mathbf{1 . 0 7 b}$ & $\mathbf{9 . 5 5} \pm \mathbf{1 . 5 7 b}$ \\
F1B0 & $2.55 \pm 1.01 \mathrm{bc}$ & $3.88 \pm 0.38 \mathrm{a}$ & $5.66 \pm 0.33 \mathrm{~b}$ & $6.88 \pm 0.50 \mathrm{ab}$ & $6.88 \pm 0.50 \mathrm{ab}$ & $7.88 \pm 2.21 \mathrm{ab}$ \\
F1B1 & $1.44 \pm 1.50 \mathrm{abc}$ & $3.77 \pm 0.38 \mathrm{a}$ & $5.88 \pm 0.50 \mathrm{~b}$ & $6.55 \pm 1.07 \mathrm{ab}$ & $7.33 \pm 0.88 \mathrm{~b}$ & $7.77 \pm 1.64 \mathrm{ab}$ \\
F1B2 & $1.00 \pm 0.00 \mathrm{abc}$ & $3.55 \pm 0.19 \mathrm{a}$ & $5.55 \pm 0.50 \mathrm{~b}$ & $5.77 \pm 0.69 \mathrm{ab}$ & $6.77 \pm 1.34 \mathrm{ab}$ & $7.11 \pm 2.00 \mathrm{ab}$ \\
F1B3 & $0.55 \pm 0.50 \mathrm{a}$ & $3.66 \pm 0.33 \mathrm{a}$ & $5.33 \pm 0.57 \mathrm{~b}$ & $6.44 \pm 0.69 \mathrm{ab}$ & $7.00 \pm 1.33 \mathrm{ab}$ & $8.11 \pm 2.69 \mathrm{ab}$ \\
F1B4 & $0.88 \pm 0.83 \mathrm{abc}$ & $3.66 \pm 0.33 \mathrm{a}$ & $5.44 \pm 0.50 \mathrm{~b}$ & $7.11 \pm 1.17 \mathrm{~b}$ & $7.22 \pm 1.01 \mathrm{~b}$ & $8.11 \pm 1.50 \mathrm{ab}$ \\
F1B5 & $0.33 \pm 0.33 \mathrm{a}$ & $2.88 \pm 1.64 \mathrm{a}$ & $3.88 \pm 2.03 \mathrm{a}$ & $4.88 \pm 2.91 \mathrm{a}$ & $5.00 \pm 2.88 \mathrm{a}$ & $5.22 \pm 3.15 \mathrm{a}$ \\
F1B6 & $1.44 \pm 1.26 \mathrm{abc}$ & $4.00 \pm 0.33 \mathrm{a}$ & $5.66 \pm 0.88 \mathrm{~b}$ & $6.66 \pm 0.66 \mathrm{ab}$ & $7.22 \pm 0.69 \mathrm{~b}$ & $8.22 \pm 0.69 \mathrm{ab}$ \\
F2B0 & $1.88 \pm 0.50 \mathrm{abc}$ & $3.88 \pm 0.69 \mathrm{a}$ & $5.22 \pm 0.69 \mathrm{ab}$ & $6.00 \pm 0.66 \mathrm{ab}$ & $5.55 \pm 0.69 \mathrm{ab}$ & $6.44 \pm 1.07 \mathrm{ab}$ \\
F2B1 & $1.88 \pm 1.07 \mathrm{abc}$ & $3.22 \pm 0.83 \mathrm{a}$ & $4.88 \pm 1.01 \mathrm{ab}$ & $5.55 \pm 1.26 \mathrm{ab}$ & $5.33 \pm 0.57 \mathrm{ab}$ & $6.33 \pm 0.88 \mathrm{ab}$ \\
F2B2 & $1.66 \pm 1.45 \mathrm{abc}$ & $3.66 \pm 0.00 \mathrm{a}$ & $4.66 \pm 0.88 \mathrm{ab}$ & $6.22 \pm 0.38 \mathrm{ab}$ & $6.44 \pm 0.38 \mathrm{ab}$ & $7.22 \pm 1.83 \mathrm{ab}$ \\
F2B3 & $0.66 \pm 0.57 \mathrm{ab}$ & $3.55 \pm 0.83 \mathrm{a}$ & $5.33 \pm 0.66 \mathrm{~b}$ & $6.44 \pm 0.83 \mathrm{ab}$ & $7.33 \pm 0.66 \mathrm{~b}$ & $7.77 \pm 1.01 \mathrm{ab}$ \\
F2B4 & $1.00 \pm 1.00 \mathrm{abc}$ & $3.77 \pm 0.19 \mathrm{a}$ & $5.88 \pm 0.38 \mathrm{~b}$ & $6.22 \pm 0.69 \mathrm{ab}$ & $6.66 \pm 0.88 \mathrm{ab}$ & $7.33 \pm 1.20 \mathrm{ab}$ \\
F2B5 & $1.22 \pm 0.69 \mathrm{abc}$ & $3.66 \pm 0.57 \mathrm{a}$ & $5.33 \pm 0.88 \mathrm{~b}$ & $7.00 \pm 1.33 \mathrm{~b}$ & $7.44 \pm 1.50 \mathrm{~b}$ & $8.33 \pm 1.15 \mathrm{ab}$ \\
F2B6 & $1.55 \pm 1.01 \mathrm{abc}$ & $3.44 \pm 0.69 \mathrm{a}$ & $5.44 \pm 0.50 \mathrm{~b}$ & $6.00 \pm 0.66 \mathrm{ab}$ & $6.66 \pm 1.00 \mathrm{ab}$ & $8.00 \pm 1.85 \mathrm{ab}$ \\
\hline
\end{tabular}

Remarks: Numbers (mean \pm sd. $n=3$ ) followed by different letters in the same column indicate significant differences, according to Duncan's Multiple Range Test (DMRT) at the $p<0.05$ level. 
Table 7. Spore AMF count, root infection and shoot dry weight of cocoa seedlings.

\begin{tabular}{cccc}
\hline $\begin{array}{c}\text { Biostructure } \\
\text { sources }\end{array}$ & $\begin{array}{c}\text { AMF spore count } \\
\left.\text { (no. } 50 \text { g soil }^{-1}\right)\end{array}$ & Root infection (\%) & Shoot dry weight (g) \\
\hline F0B0 & $16 \pm 4.70 \mathrm{a}$ & $16.66 \pm 17.64 \mathrm{a}^{\mathrm{ns}}$ & $2.71 \pm 0.46 \mathrm{a}^{\mathrm{ns}}$ \\
F1B0 & $19 \pm 4.63 \mathrm{a}$ & $36.66 \pm 20.28 \mathrm{a}$ & $2.14 \pm 0.09 \mathrm{a}$ \\
F1B1 & $30 \pm 5.56 \mathrm{ab}$ & $33.33 \pm 15.28 \mathrm{a}$ & $2.58 \pm 0.52 \mathrm{a}$ \\
F1B2 & $33 \pm 9.89 \mathrm{ab}$ & $24.44 \pm 13.47 \mathrm{a}$ & $1.91 \pm 0.37 \mathrm{a}$ \\
F1B3 & $26 \pm 9.33 \mathrm{ab}$ & $27.77 \pm 21.17 \mathrm{a}$ & $1.88 \pm 0.46 \mathrm{a}$ \\
F1B4 & $15 \pm 7.58 \mathrm{a}$ & $21.11 \pm 25.24 \mathrm{a}$ & $2.08 \pm 1.06 \mathrm{a}$ \\
F1B5 & $24 \pm 12.60 \mathrm{ab}$ & $30.00 \pm 18.56 \mathrm{a}$ & $2.38 \pm 0.43 \mathrm{a}$ \\
F1B6 & $38 \pm 7.40 \mathrm{~b}$ & $32.22 \pm 13.47 \mathrm{a}$ & $2.42 \pm 0.61 \mathrm{a}$ \\
F2B0 & $23 \pm 5.34 \mathrm{ab}$ & $28.88 \pm 25.47 \mathrm{a}$ & $1.88 \pm 0.45 \mathrm{a}$ \\
F2B1 & $23 \pm 7.21 \mathrm{ab}$ & $13.33 \pm 3.33 \mathrm{a}$ & $2.24 \pm 0.55 \mathrm{a}$ \\
F2B2 & $28 \pm 12.72 \mathrm{ab}$ & $33.33 \pm 31.80 \mathrm{a}$ & $1.86 \pm 0.92 \mathrm{a}$ \\
F2B3 & $32 \pm 7.18 \mathrm{ab}$ & $10.00 \pm 5.77 \mathrm{a}$ & $2.09 \pm 0.53 \mathrm{a}$ \\
F2B4 & $32 \pm 12.25 \mathrm{ab}$ & $13.33 \pm 12.02 \mathrm{a}$ & $1.77 \pm 0.22 \mathrm{a}$ \\
F2B5 & $28 \pm 7.50 \mathrm{ab}$ & $22.22 \pm 10.72 \mathrm{a}$ & $1.86 \pm 0.81 \mathrm{a}$ \\
F2B6 & $29 \pm 11.57 \mathrm{ab}$ & $8.88 \pm 1.92 \mathrm{a}$ & $2.85 \pm 1.44 \mathrm{a}$ \\
\hline
\end{tabular}

Remarks: Numbers (mean \pm sd. $n=3$ ) followed by different letters in the same column indicate significant differences according to Duncan's Multiple Range Test (DMRT) at the $p<0.05$ level.

The highest total AMF spore count in the biostructure was obtained using earthworm and ant populations in a 20:10 (individual/individual) ratio on G. sepium leaf and cocoa bean shell in a 50\%:50\% composition (Figure 3). This indicates the AMF spore density increased with increasing earthworm-ant ratio, confirming the presence of ants plays an important role in improving the soil $\mathrm{pH}$, organic- $\mathrm{C}, \mathrm{N}$, and $\mathrm{P}$ contents (Almeida et al., 2019; Boots et al., 2012). Therefore, improved $\mathrm{pH}$, organic- $\mathrm{C}, \mathrm{N}$, and $\mathrm{P}$ through bioturbation by ants,createsmore suitable conditions for earthworm activity to form new biostructures (Sankar \& Patnaik, 2018; Taylor et al., 2019). In addition, the biostructures' environmental condition derived from the treatments modulates the growth of AMF spore populations (de Menezes et al., 2018; Lucas et al., 2017). The high density of AMF spores in the biostructure formed from a mixed composition of the organic matter types indicates the quality of food resources and the available conditions are suitable for collaboration between Peryonix sp. and Dorylus $\mathrm{sp}$. In the present work, the addition of sago dregs to the organic matter mixture tended to decrease the spore density (Figure 3). Regarding the chemical attributes of the three organic matter types tested, sago dreg has a higher total- $\mathrm{C}$ and $\mathrm{C} / \mathrm{N}$ ratio, but lower total- $\mathrm{N}$, total- $\mathrm{P}$, and total- $\mathrm{K}$ contents, compared to cocoa shell beans and $G$. Sepiumleaves (Table 1). This is comparable with the report by Syaf et al. (2021), where the AMF spore density in the biostructure containing biochar decreased with the increasing earthworm population. Biochar is known to have high total- $\mathrm{C}$ and $\mathrm{C} / \mathrm{N}$ and low nutrient content (Prasad et al., 2020), therefore, these results reaffirm that organic quality (total- $\mathrm{C}, \mathrm{C} / \mathrm{N}$ ratio, total- $\mathrm{N}, \mathrm{P}$, and K) has the capacity to affect AMF spore populations in soil biostructure created through activities of soil fauna ecosystem engineers (Medina-Sauza et al., 2019).
This study's results discovered the total number of spores in rhizospheric soil from cocoa seedlings subjected to biostructure treatments, tend to be more, compared to seedlings subjected to soil applications without the ecosystem engineering soil fauna's activities, while the percentage of infected roots differed insignificantly (Table 7). This indicates AMF spores carried by biostructures formed through the collaborative activity of ants and earthworms in soil from the smallholder cocoa plantation mixed with different types of organic matter, are able to germinate and produce hyphae infective to the cocoa seedlings' roots. The highest number of spores in rhizospheric soil was obtained from the application of biostructures containing the highest amount of AMF spore. A study by (Harinikumar \& Bagyaraj, 1994) also found earthworm casts and ant nests contained viable AMF spores infective to Allium cepa roots grown in sterilized soil. In this study, the inoculation of spores carried by the biostructure was performed under the conditions of cocoa seedlings grown on un-sterilized soil.

The large number of spores carried by the biostructure is the expected percentage of infected roots, but is also more, in some cases (Verbruggen et al., 2013). However, the results found another case, where the percentage of infected cocoa seedling roots differed insignificantly between treatments. This value ranged from $8.88 \%-36.66 \%$ in all treatments, and was lower, compared to roots infected by arbuscular mycorrhizae from cocoa seedlings grown on sterilized soil (Aggangan et al., 2019). The success of AMF spore inoculation under unsterilized growing media is determined by biotic factors through an inhibitory mechanism (Fukami, 2015), the spore community inhabiting the growth media has the potential to suppress the performance of pores carried by inoculum source material to infect roots (Werner \& Kiers, 
2015). Furthermore, the inhibitory effect's strength is supported by the nutrient availability in the growth media (Cely et al., 2016; Hayashi et al., 2018)

The percentage of infected roots did not differ significantly between the control and biostructures treatments. However, the plant height and the number of leaves were higher in the control, compared to the biostructure treatments (Table 5 and 6), but the seedling's shoot dry weight was insignificant (Table 7). A study by Bagy Araji and Powell (1985) showed AMF application increased the height and stem diameter of marigolds grown in pots filled with unsterilized mineral soil with a characteristic $\mathrm{pH}$ and available $P$ of 5.4 and $9 \mu \mathrm{g} / \mathrm{l}$, respectively. Meanwhile, Mau and Utami (2014) reported mycorrhizal spore inoculation did not show an increase in height for maize plants grown on un-sterilized soil dominated by sandy loam with a $7.02 \mathrm{pH}$. Also, Aggangan et al. (2019) reported the soilbased inoculant powder containing AMF spores increased the dry weight of inoculated cacao seedlings on non-sterilized soil enhanced with NPK fertilizer. In a report by Kim et al. (2017), inorganic fertilizer led to a higher increase in the dry weight of plants without spore inoculation, compared to counterparts inoculated with spores on sterile soil. Thus, this study's results reaffirm the stoichiometry of soil ecology largely determining the mutualistic-parasitic symbiosis continuum in interactions between the spores and plant roots grown on soil under field conditions (Mandyam \& Jumpponen, 2015).

\section{CONCLUSION}

The AMF spore density in the biostructure was affected by the composition of earthworms and ants, as well as the composition of organic matter mix added to the soil. In addition, the spore abundance was positively correlated with total, $\mathrm{P}$, and negatively with the $\mathrm{C} / \mathrm{N}$ ratio. The biostructure applied has the capacity to increase the total number of spores in the rhizospheric soil and roots infection from cocoa seedlings growing on non-sterile soils. However, further studies are required to understand soil quality factors with the most contribution to a positive association between AMF spores carried through biostructure treatment.

\section{Declaration of Competing Interest}

The authors declare no competing financial or personal interests that may appear and influence the work reported in this paper

\section{References}

Aggangan, N. S., Cortes, A. D., \& Reaño, C. E. (2019). Growth response of cacao (Theobroma cacao L.) plant as affected by bamboo biochar and arbuscular mycorrhizal fungi in sterilized and unsterilized soil. Biocatalysis and Agricultural Biotechnology, 22, 101347. https://doi.org/10.1016/j.bcab.2019.101347

Alimi, A., Adeleke, R., \& Moteetee, A. (2021). Soil environmental factors shape the rhizosphere arbuscular mycorrhizal fungal communities in South African indigenous legumes (Fabaceae). Biodiversitas
Journal of Biological Diversity, 22(5). https://doi.org/10.13057/biodiv/d220503

Almeida, A., Mitchell, A. L., Boland, M., Forster, S. C., Gloor, G. B., Tarkowska, A., Lawley, T. D., \& Finn, R. D. (2019). A new genomic blueprint of the human gut microbiota. Nature, 568(7753), 499-504. https://doi.org/10.1038/s41586-019-0965-1

Asano, K., Kagong, W. V. A., Mohammad, S. M. B., Sakazaki, K., Talip, M. S. A., Sahmat, S. S., Chan, M. K. Y., Isoi, T., Kano-Nakata, M., \& Ehara, H. (2021). Arbuscular Mycorrhizal Communities in the Roots of Sago Palm in Mineral and Shallow Peat Soils. Agriculture, 11(11), 1161. https://doi.org/10.3390/agriculture11111161

Azizah Chulan, H. (1991). Effect of fertilizer and endomycorrhizal inoculum on growth and nutrient uptake of cocoa (Theobroma cacao L.) seedlings. Biology and Fertility of Soils, 11(4), 250-254. https://doi.org/10.1007/BF00335843

Bagy Araji, D. J., \& Powell, C. L. (1985). Effect of vesiculararbuscular mycorrhizal inoculation and fertiliser application on the growth of marigold. New Zealand Journal of Agricultural Research, 28(1), 169-173. https://doi.org/10.1080/00288233.1985.10427012

Bahrun, A., Fahimuddin, M., Safuan, L., Kilowasid, L. M., \& Singh, R. (2018). Effects of cocoa pod husk biochar on growth of cocoa seedlings in Southeast SulawesiIndonesia. Asian J. Crop Sci, 10(1), 22-33. https://doi.org/10.3923/ajcs.2018.22.30

Boots, B., Keith, A. M., Niechoj, R., Breen, J., Schmidt, O., \& Clipson, N. (2012). Unique soil microbial assemblages associated with grassland ant species with different nesting and foraging strategies. Pedobiologia, 55(1), 33-40. https://doi.org/10.1016/j.pedobi.2011.10.004

Bottinelli, N., Jouquet, P., Capowiez, Y., Podwojewski, P., Grimaldi, M., \& Peng, X. (2015). Why is the influence of soil macrofauna on soil structure only considered by soil ecologists? Soil and Tillage Research, 146, 118124. https://doi.org/10.1016/j.still.2014.01.007

Briones, M. J. I. (2014). Soil fauna and soil functions: a jigsaw puzzle [Review]. Frontiers in Environmental Science, 2(7). https://doi.org/10.3389/fenvs.2014.00007

Cely, M. V. T., de Oliveira, A. G., de Freitas, V. F., de Luca, M. B., Barazetti, A. R., dos Santos, I. M. O., Gionco, B., Garcia, G. V., Prete, C. E. C., \& Andrade, G. (2016). Inoculant of Arbuscular Mycorrhizal Fungi (Rhizophagus clarus) Increase Yield of Soybean and Cotton under Field Conditions [Original Research]. Frontiers in Microbiology, 7(720). https://doi.org/10.3389/fmicb.2016.00720

Cobb, A. B., Wilson, G. W. T., Goad, C. L., \& Grusak, M. A. (2018). Influence of alternative soil amendments on mycorrhizal fungi and cowpea production. Heliyon, 4(7). https://doi.org/10.1016/j.heliyon.2018.e00704

Cunha, L., Brown, G. G., Stanton, D. W. G., Da Silva, E., Hansel, F. A., Jorge, G., McKey, D., Vidal-Torrado, P., Macedo, R. S., Velasquez, E., James, S. W., Lavelle, P., Kille, P., \& Network, t. T. P. d. I. (2016). Soil Animals and Pedogenesis: The Role of Earthworms in 
Anthropogenic Soils. Soil Science, 181(3/4), 110-125. https://doi.org/10.1097/ss.0000000000000144

de Menezes, A. B., Prendergast-Miller, M. T., Macdonald, L. M., Toscas, P., Baker, G., Farrell, M., Wark, T., Richardson, A. E., \& Thrall, P. H. (2018). Earthworminduced shifts in microbial diversity in soils with rare versus established invasive earthworm populations. FEMS Microbiology Ecology, 94(5), fiy051. https://doi.org/10.1093/femsec/fiy051

Dhar, P. P., \& Mridha, M. A. U. (2012). Arbuscular mycorrhizal associations in different forest tree species of Hazarikhil forest of Chittagong, Bangladesh. Journal of Forestry Research, 23(1), 115-122. https://doi.org/10.1007/s11676-012-0241-9

Directorate General of Estates. (2019). Tree Crop Estate Stitistics of Indonesia 2018-2020: Cocoa. Secretariate of Directorate General of Estates, Directorate General of Estates, Ministry of Agriculture. https://ditjenbun.pertanian.go.id/?publikasi=bukupublikasi-statistik-2018-2020

Ehrle, A., Potthast, K., Tischer, A., Trumbore, S. E., \& Michalzik, B. (2019). Soil properties determine how Lasius flavus impact on topsoil organic matter and nutrient distribution in central Germany. Applied Soil Ecology, 133, 166-176. https://doi.org/10.1016/j.apsoil.2018.08.021

Forey, E., Chauvat, M., Coulibaly, S. F. M., Langlois, E., Barot, S., \& Clause, J. (2018). Inoculation of an ecosystem engineer (Earthworm: Lumbricus terrestris) during experimental grassland restoration: Consequences for above and belowground soil compartments. Applied Soil Ecology, 125, 148-155. https://doi.org/10.1016/j.apsoil.2017.12.021

Franco, A. L. C., Cherubin, M. R., Cerri, C. E. P., Guimarães, R. M. L., \& Cerri, C. C. (2017). Relating the visual soil structure status and the abundance of soil engineering invertebrates across land use change. Soil and Tillage Research, 173 ,

49-52. https://doi.org/10.1016/j.still.2016.08.016

Fukami, T. (2015). Historical contingency in community assembly: integrating niches, species pools, and priority effects. Annual Review of Ecology, Evolution, and Systematics, 46, 1-23. https://doi.org/10.1146/annurev-ecolsys-110411160340

Harinikumar, K. M., \& Bagyaraj, D. J. (1994). Potential of earthworms, ants, millipedes, and termites for dissemination of vesicular-arbuscular mycorrhizal fungi in soil. Biology and Fertility of Soils, 18(2), 115118. https://doi.org/10.1007/BF00336456

Hayashi, M., Niwa, R., Urashima, Y., Suga, Y., Sato, S., Hirakawa, H., Yoshida, S., Ezawa, T., \& Karasawa, T. (2018). Inoculum effect of arbuscular mycorrhizal fungi on soybeans grown in long-term bare-fallowed field with low phosphate availability. Soil Science and Plant Nutrition, 64(3), 306-311. https://doi.org/10.1080/00380768.2018.1473007

INVAM. (2019). Enumeration of Spores. International Culture Collection of (Vesicular) Arbuscular Mycorrhizal Fungi,
West Virginia University. https://invam.wvu.edu/methods/spores/enumeratio n-of-spores

Jouquet, P., Janeau, J.-L., Pisano, A., Sy, H. T., Orange, D., Minh, L. T. N., \& Valentin, C. (2012). Influence of earthworms and termites on runoff and erosion in a tropical steep slope fallow in Vietnam: A rainfall simulation experiment. Applied Soil Ecology, 61, 161168. https://doi.org/10.1016/j.apsoil.2012.04.004

Kameoka, H., Tsutsui, I., Saito, K., Kikuchi, Y., Handa, Y., Ezawa, T., Hayashi, H., Kawaguchi, M., \& Akiyama, K. (2019). Stimulation of asymbiotic sporulation in arbuscular mycorrhizal fungi by fatty acids. Nature Microbiology, 4(10), 1654-1660. https://doi.org/10.1038/s41564-019-0485-7

Kilowasid, L. M. H., Budianto, W., Syaf, H., Tufaila, M., \& Safuan, L. O. (2015). Using of ants and earthworm to modify of soil biological quality and its effect on cocoa seedlings growth. AIP Conference Proceedings, 1677(1), 110004. https://doi.org/10.1063/1.4930775

Kim, S. J., Eo, J.-K., Lee, E.-H., Park, H., \& Eom, A.-H. (2017). Effects of Arbuscular Mycorrhizal Fungi and Soil Conditions on Crop Plant Growth. Mycobiology, 45(1), 20-24. https://doi.org/10.5941/MYCO.2017.45.1.20

Lavelle, P., Spain, A., Blouin, M., Brown, G., Decaëns, T., Grimaldi, M., Jiménez, J. J., McKey, D., Mathieu, J., Velasquez, E., \& Zangerlé, A. (2016). Ecosystem Engineers in a Self-organized Soil: A Review of Concepts and Future Research Questions. Soil Science, 181(3/4). https://doi.org/10.1097/SS.0000000000000155

Lee, K. K., Reddy, M. V., Wani, S. P., \& Trimurtulu, N. (1996). Vesicular-arbuscular mycorrhizal fungi in earthworm casts and surrounding soil in relation to soil management of a semi-arid tropical Alfisol. Applied Soil Ecology, 3(2), 177-181. https://doi.org/10.1016/0929-1393(95)00082-8

Lucas, J., Bill, B., Stevenson, B., \& Kaspari, M. (2017). The microbiome of the ant-built home: the microbial communities of a tropical arboreal ant and its nest. Ecosphere, 8(2), e01639. https://doi.org/10.1002/ecs2.1639

Mandyam, K. G., \& Jumpponen, A. (2015). Mutualismparasitism paradigm synthesized from results of rootendophyte models [Hypothesis and Theory]. Frontiers in Microbiology, 5(776). https://doi.org/10.3389/fmicb.2014.00776

Mau, A. E., \& Utami, S. R. (2014). Effects of biochar amendment and arbuscular mycorrhizal fungi inoculation on availability of soil phosphorus and growth of maize [arbuscular mycorrhizal fungi; biochar; calcareous soil; maize; phosphorus uptake]. 2014, 1(2), https://doi.org/10.15243/jdmlm.2014.012.069

Medina-Sauza, R. M., Álvarez-Jiménez, M., Delhal, A., Reverchon, F., Blouin, M., Guerrero-Analco, J. A., Cerdán, C. R., Guevara, R., Villain, L., \& Barois, I. (2019). Earthworms Building Up Soil Microbiota, a Review [Systematic Review]. Frontiers in Environmental 
Science, https://doi.org/10.3389/fenvs.2019.00081

$7(81)$

Mei, L., Yang, X., Cao, H., Zhang, T., \& Guo, J. (2019). Arbuscular Mycorrhizal Fungi Alter Plant and Soil C:N:P Stoichiometries Under Warming and Nitrogen Input in a Semiarid Meadow of China. International Journal of Environmental Research and Public Health, 16(3), 397. https://doi.org/10.3390/ijerph16030397

Melo, C. D., Walker, C., Krüger, C., Borges, P. A. V., Luna, S., Mendonça, D., Fonseca, H. M. A. C., \& Machado, A. C. (2019). Environmental factors driving arbuscular mycorrhizal fungal communities associated with endemic woody plant Picconiaazorica on native forest of Azores. Annals of Microbiology, 69(13), 1309-1327. https://doi.org/10.1007/s13213-019-01535-x

Moreira, S. D., França, A. C., Rocha, W. W., Tibães, E. S., \& Neiva, E. (2018). Inoculation with mycorrhizal fungi on the growth and tolerance to water deficit of coffee plants. Revista Brasileira de Engenharia Agrícola $e$ Ambiental, 22,

https://doi.org/10.1590/1807-

1929/agriambi.v22n11p747-752

Powell, C. L., \& Bagyaraj, D. J. (2017). Va Mycorrhizae: Why all the Interest? In C. L. Powell \& D. J. Bagyaraj (Eds.), VA Mycorrhiza. CRC Press. https://doi.org/10.1201/9781351077514

Prasad, M., Chrysargyris, A., McDaniel, N., Kavanagh, A., Gruda, N. S., \& Tzortzakis, N. (2020). Plant Nutrient Availability and $\mathrm{pH}$ of Biochars and Their Fractions, with the Possible Use as a Component in a Growing Media. Agronomy, 10(1), 10 https://doi.org/10.3390/agronomy10010010

Rillig, M. C., Aguilar-Trigueros, C. A., Anderson, I. C., Antonovics, J., Ballhausen, M.-B., Bergmann, J., Bielcik, M., Chaudhary, V. B., Deveautour, C., Grünfeld, L., Hempel, S., Lakovic, M., Lammel, D. R., Lehmann, A., Lehmann, J., Leifheit, E. F., Liang, Y., Li, E., Lozano, Y. M., Manntschke, A., Mansour, I., Oviatt, P., Pinek, L., Powell, J. R., Roy, J., Ryo, M., Sosa-Hernández, M. A., Veresoglou, S. D., Wang, D., Yang, G., \& Zhang, H. (2020). Myristate and the ecology of AM fungi: significance, opportunities, applications and challenges. New Phytologist, 227(6), 1610-1614. https://doi.org/10.1111/nph.16527

Salim, M. A., Budi, S. W., Setyaningsih, L., Iskandar, Wahyudi, I., \& Kirmi, H. (2020). Root colonization by arbuscular mycorrhizal fungi (AMF) in various age classes of revegetation post-coal mine. Biodiversitas Journal of Biological Diversity, 21(11). https://doi.org/10.13057/biodiv/d211105

Sanjaya, M. F., Kilowasid, L. M. H., Sabaruddin, L., Sulaeman, D., \& Nurmas, A. (2020). Pengaruh Bahan Organik terhadap Spora Fungi Mikoriza Arbuskula dalam Tanah, dan Potensi Tanahnya Sebagai Sumber Inokulum. Berkala Penelitian Agronomi, 8(1), 11-22. http://ojs.uho.ac.id/index.php/agronomi/article/view $/ 12938$

Sankar, A. S., \& Patnaik, A. (2018). Impact of soil physicochemical properties on distribution of earthworm populations across different land use patterns in southern India. The Journal of Basic and Applied Zoology, 79(1), 50. https://doi.org/10.1186/s41936018-0066-y

Schultz, T. R., Sosa-Calvo, J., Brady, S. G., Lopes, C. T., Mueller, U. G., BacciJr., M., \& Vasconcelos, H. L. (2015). The Most Relictual Fungus-Farming Ant Species Cultivates the Most Recently Evolved and Highly Domesticated Fungal Symbiont Species. The American Naturalist, 185(5), 693-703. https://doi.org/10.1086/680501

Seutra Kaba, J., Abunyewa, A. A., Kugbe, J., Kwashie, G. K. S., Owusu Ansah, E., \& Andoh, H. (2021). Arbuscular mycorrhizal fungi and potassium fertilizer as plant biostimulants and alternative research for enhancing plants adaptation to drought stress: Opportunities for enhancing drought tolerance in cocoa (Theobroma cacao L.). Sustainable Environment, 7(1), 1963927. https://doi.org/10.1080/27658511.2021.1963927

Shukla, R. K., Singh, H., \& Rastogi, N. (2016). How effective are disturbance - tolerant, agroecosystem - nesting ant species in improving soil fertility and crop yield? Applied Soil Ecology, 108, 156-164. https://doi.org/10.1016/j.apsoil.2016.08.013

Sivakumar, N. (2013). Effect of edaphic factors and seasonal variation on spore density and root colonization of arbuscular mycorrhizal fungi in sugarcane fields. Annals of Microbiology, 63(1), 151-160. https://doi.org/10.1007/s13213-012-0455-2

Sugiura, Y., Akiyama, R., Tanaka, S., Yano, K., Kameoka, H., Marui, S., Saito, M., Kawaguchi, M., Akiyama, K., \& Saito, K. (2020). Myristate can be used as a carbon and energy source for the asymbiotic growth of arbuscular mycorrhizal fungi. Proceedings of the National Academy of Sciences, 117(41), 25779. https://doi.org/10.1073/pnas.2006948117

Syaf, H., Pattah, M. A., \& Kilowasid, L. M. H. (2021). Quality of soil from the nickel mining area of Southeast Sulawesi, Indonesia, engineered using earthworms (Pheretima sp.) [biostructure; ecosystem engineer; soil ecological engineering; soil quality]. 2021, 8(4), 11. https://doi.org/10.15243/jdmlm.2021.084.2995

Taylor, A. R., Lenoir, L., Vegerfors, B., \& Persson, T. (2019). Ant and Earthworm Bioturbation in Cold-Temperate Ecosystems. Ecosystems, 22(5), 981-994. https://doi.org/10.1007/s10021-018-0317-2

Verbruggen, E., van der Heijden, M. G. A., Rillig, M. C., \& Kiers, E. T. (2013). Mycorrhizal fungal establishment in agricultural soils: factors determining inoculation success. New Phytologist, 197(4), 1104-1109. https://doi.org/10.1111/j.1469-8137.2012.04348.x

Verzeaux, J., Nivelle, E., Roger, D., Hirel, B., Dubois, F., \& Tetu, T. (2017). Spore Density of Arbuscular Mycorrhizal Fungi is Fostered by Six Years of a No-Till System and is Correlated with Environmental Parameters in a Silty Loam Soil. Agronomy, 7(2), 38. https://doi.org/10.3390/agronomy7020038

Vogt, D. J., Tilley, J. P., \& Edmonds, R. L. (2015). Soil and Plant Analysis for Forest Ecosystem Characterization. Berlin, 
München, Boston: De Gruyter. https://doi.org/10.1515/9783110290479

Wang, P., Wang, Y., Shu, B., Liu, J.-F., \& Xia, R.-X. (2015). Relationships Between Arbuscular Mycorrhizal Symbiosis and Soil Fertility Factors in Citrus Orchards Along an Altitudinal Gradient. Pedosphere, 25(1), 160168. https://doi.org/10.1016/S1002-0160(14)60086-2

Wang, S., Li, J., Zhang, Z., Chen, M., Li, S., \& Cao, R. (2019). Feeding-strategy effect of Pheidole ants on microbial carbon and physicochemical properties in tropical forest soils. Applied Soil Ecology, 133, 177-185. https://doi.org/10.1016/j.apsoil.2018.10.006

Werner, G. D. A., \& Kiers, E. T. (2015). Order of arrival structures arbuscular mycorrhizal colonization of plants. New Phytologist, 205(4), 1515-1524. https://doi.org/10.1111/nph.13092

Wills, B. D., \& Landis, D. A. (2018). The role of ants in north temperate grasslands: a review. Oecologia, 186(2), 323-338. https://doi.org/10.1007/s00442-017-4007-0

Zanella, A., Ponge, J.-F., \& Briones, M. J. I. (2018). Humusica 1, article 8: Terrestrial humus systems and forms Biological activity and soil aggregates, space-time dynamics. Applied Soil Ecology, 122, 103-137. https://doi.org/10.1016/j.apsoil.2017.07.020

Zanella, A., Ponge, J.-F., Topoliantz, S., Bernier, N., \& Juilleret, J. (2018). Humusica 2, Article 15: Agro humus systems and forms. Applied Soil Ecology, 122, 204-219. https://doi.org/10.1016/j.apsoil.2017.10.011 